\title{
Record of Leptoglossus cinctus (Hemiptera: Coreidae) associated with the native tree Byrsonima sericea (Malpighiaceae) and the cashew tree Anacardium occidentale (Anacardiaceae)
}

\author{
I. M. M. Lima ${ }^{a}$, L. V. Nascimento ${ }^{a}, J$. V. L. Firmino ${ }^{*}$, J. A. M. Fernandes ${ }^{b}$, \\ J. Grazia ${ }^{c}$, A. C. M. Malhado and R. P. Lyra-Lemos ${ }^{d}$

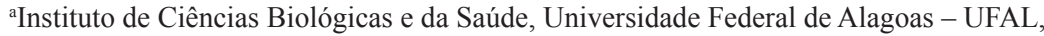 \\ Av. Lourival Melo Mota, s/n, Cidade Universitária, CEP 57072-970, Maceió, AL, Brazil \\ 'Instituto de Ciências Biológicas, Universidade Federal do Pará - UFPA, \\ Rua Augusto Corrêa, 1, Guamá, CEP 66075-110, Belém, PA, Brazil \\ 'Instituto de Biociências, Universidade Federal do Rio Grande do Sul - UFRGS, \\ Av. Bento Gonçalves, 9500, Campus do Vale, CEP 91501-970, Porto Alegre, RS, Brazil \\ 'Instituto do Meio Ambiente do Estado de Alagoas - IMA, Av. Major Cícero de Góes Monteiro, 2197, \\ Mutange, CEP 57017-515, Maceió, AL, Brazil \\ *e-mail: joaovlfirmino@outlook.com
}

Received: June 6, 2016 - Accepted: August 20, 2016 - Distributed: February 28, 2018

Coreids of the genus Leptoglossus Guérin (Coreinae) comprise a large group of phytophagous insects that are characterized by dilated posterior tibiae in the form of a leaf - the so-called leaf-footed bugs. They are widely distributed across the Americas, ranging from southern Canada to Chile and Argentina (Schaefer et al., 2008). Among the known species, only Leptoglossus gonagra (Fabricius) has been recorded outside the Western Hemisphere, with records from Africa, Asia, the Pacific Islands and Australia (Allen, 1969; Brailovsky and Barrera, 1998; Schaefer et al., 2008). Out of the 61 currently described Leptoglossus species (Roskov et al., 2015), 19 have been recorded in Brazil and another six species probably occur there, since they have been registered in neighboring countries - Venezuela, Uruguay, and Argentina (Schaefer et al., 2008).

Information on the food plant preferences of coreids is of central importance for pest management and for the establishment of phylogenetic relationships (Schaefer and Mitchell, 1983). However, records of host plant associations are extremely scarce for the vast majority of phytophagous insects in Brazil, being mainly restricted to key species of agricultural interest or vectors of diseases (Flinte et al., 2006). This lack of records includes the species of the genus Leptoglossus, especially with respect to their possible associations with wild plants in the border regions of plantations. Such associations could significantly contribute to the persistence of the pest species in the agroecosystem. In this short note we provide data on two new associations of a Leptoglossus species from the Atlantic Forest of northeast Brazil.

Voucher specimens, nymphs of different instars $(n=11)$ and adults $(\mathrm{n}=5)$ were collected from leaves and fruits on the plant branches of the native Malpighiaceae tree, located in the Atlantic Woods of the "Catolé" (09³3.6'S and $35^{\circ} 47.7^{\prime} \mathrm{W}$ ), a fragment of Atlantic Forest Biome, in the municipality of Maceió, State of Alagoas, Brazil.
Also, voucher specimens, seven adults were collected from the leaves and fruits of Anacardium tree (Anacardiaceae) in the border area of other Atlantic Forest fragment, municipality of Paripueira (09 $27.5^{\prime} \mathrm{S}$ and $35^{\circ} 33.3^{\prime} \mathrm{W}$ ). Insects were collected manually and with beating trays in April 2011 (Maceió) and manually in February 2012 (Paripueira). Adults were killed by freezing and nymphs were kept in plastic containers and fed on leaves and fruits of the host plant. Dead nymphs were placed in receptacles containing $70 \%$ alcohol. Adults were pinned for kiln drying. Species were identified based on the keys of Allen (1969) and were deposited in the entomological collection of Museu Paraense Emilio Goeldi, Belém, State of Pará, Brazil and entomological collection of Universidade Federal de Alagoas, Maceió, State of Alagoas, Brazil.

Native host plants were dried and deposited ( $\left.\mathrm{N}^{\circ} 42116\right)$ in the Herbarium MAC of the Instituto do Meio Ambiente do Estado de Alagoas (IMA). The collection procedures were authorized by Instituto Chico Mendes de Conservação da Biodiversidade (ICMBio), through the license granted in April 2011 (Registration No. 27642-1).

Nymphs reared in laboratory conditions did not reach the adult stage. Adults from the field were identified as Leptoglossus cinctus (Herrich-Schäffer) (Coreinae: Anisoscelini), a Neotropical species distributed from Mexico to southern South America, with records for the following countries: Mexico, Cuba, Honduras, Costa Rica, Panama, Guyana, French Guiana, Venezuela, Colombia, Brazil, Peru, Bolivia, Paraguay, and Argentina (Allen, 1969).

Leptoglossus cinctus has previously been recorded in Southeast, North and Midwest Brazil, in the following states: Amazonas, Pará, Mato Grosso, Goiás, Distrito Federal, Mato Grosso do Sul, Minas Gerais, Rio Grande do Norte, Rio de Janeiro and São Paulo (Allen, 1969; Jurberg and Felippe, 1981). 
The native food plant species was identified as Byrsonima sericea DC (Malpighiaceae). This tree is a common representative of the upper stratum of the Brazilian Atlantic Forest. Byrsonima. sericea is shade intolerant and is predominantly associated with disturbed areas or edge habitats (Oliveira-Filho et al., 2004). The genus Byrsonima, with about 150 species, is a large group of trees popularly known in Brazil as "murici". Several groups of insects have already been recorded in association with these trees in the Neotropics (Flinte et al., 2006).

The other host plant species was the cashew nut tree, Anacardium occidentale L. (Anacardiaceae), a crop plant with high economic value. The production and commercial exploitation of the fruit of $A$. occidentale is an important component of the agricultural industry in countries such as India, Brazil, Mozambique, Tanzania and Kenya. In addition to the famous cashew 'nut' (actually the fruit), the shell liquid can be used as a source of phenol for various industrial purposes (Embrapa, 1991). Existing records of cashew pests include the coreid Leptoglossus stigma (Herbst, 1784). These insects occur mainly in the fruiting period, causing the loss of quality and production of nuts (Mesquita et al., 2002; Bleicher and Melo, 1996).

There are a few existing records of associations between $L$. cinctus and native plants, specifically $B$. crassifolia L. and the cactus genera Opuntia and Cereus (Cactaceae) (Allen, 1969; Schaefer and Mitchell, 1983). However, these records do not indicate the deposition of herbarium material or provide accurate geo-referenced locations. Benezar and Pessoni (2006) reported the presence of Leptoglossus on fruits of B. coccolobifolia Kunth in an Amazonian savanna in Roraima state in the north of Brazil. Leptoglossus cinctus has also been recorded on Psidium guajava L. (Guava) (Myrtaceae) (Allen, 1969; Schaefer and Mitchell, 1983) and tomatoes (Solanaceae) (Mitchell, 2004), indicating their propensity to attack different families of plants of agricultural importance. Given that other Leptoglossus species are already included in the list of cashew pests, a new record of L. cinctus associated with these plants requires further investigation and risk assessment.

\section{Acknowledgements}

We thank Edalves M. Gonçalves by donation of specimens of L. cinctus from his orchard in Paripueira municipality and Conselho Nacional de Desenvolvimento Científico e Tecnológico for financial support to Jocelia Grazia and José A. M. Fernandes. We thank Professor Richard J. Ladle for reviewing the manuscript and Kim R. Barão for the suggestions.

\section{References}

ALLEN, R.C., 1969. A revision of the genus Leptoglossus Guerin (Hemiptera: Coreidae). Entomologica Americana, vol. 45 , pp. 35-140.
BENEZAR, R.M.C. and PESSONI, L.A., 2006. Biologia floral e sistema reprodutivo de Byrsonima coccolobifolia (Kunth) em uma savana amazônica. Acta Amazonica, vol. 36, no. 2, pp. 159-168. http://dx.doi.org/10.1590/S0044-59672006000200005.

BLEICHER, E. and MELO, Q.M.S., 1996. Artrópodes associados ao cajueiro no Brasil. 2. ed. Fortaleza: Embrapa-CNPAT. 35 p. Embrapa-CNPAT. Documentos, no. 9.

BRAILOVSKY, H. and BARRERA, E., 1998. A review of the Costa Rican species of Leptoglossus Guerin, with descriptions of two new species (Hemiptera: Heteroptera: Coreidae: Coreinae: Anisoscelini). Proceedings of the California Academy of Sciences, vol. 50, no. 6 , pp. 167-184.

EMPRESA BRASILEIRA DE PESQUISA AGROPECUÁRIA - EMBRAPA, 1991. Programa Nacional de Pesquisa de Caju. Fortaleza: Embrapa-Cnpca. 59 p. Embrapa-CNPCa. Documentos, no. 5 .

FLINTE, V., ARAÚJO, C.O., MACEDO, M.V. and MONTEIRO, R.F., 2006. Insetos fitófagos associados ao murici da praia, Byrsonima sericea (Malpighiaceae), na Restinga de Jurubatiba (RJ). Revista Brasileira de Entomologia, vol. 50, no. 4, pp. 512-523. http://dx.doi.org/10.1590/S0085-56262006000400012.

JURBERG, J. and FELIPPE, M.L., 1981. Estudo morfológico comparativo de Leptoglossus cinctus (H. Schaeffer,1836) e Leptoglossus fasciatus (Westwood, 1942) e suas genitálias (Hemiptera: Coreidae). Revista Brasileira de Biologia =. Brazilian Journal of Biology $=$ Revista Brasileira de Biologia, vol. 41, no. 2, pp. 407-420.

MESQUITA, A.L.M., BRAGA-SOBRINHO, R. and OLIVEIRA, V.H., 2002. Monitoramento de pragas na cultura do cajueiro. Fortaleza: Embrapa Agroindústria Tropical. 36 p. Embrapa Agroindústria Tropical. Documentos, no. 48.

MITCHELL, P.L., 2004. Heteroptera as Vectors of Plant Pathogens. Neotropical Entomology, vol. 33, no. 5, pp. 519-545. http://dx.doi. org/10.1590/S1519-566X2004000500001.

OLIVEIRA-FILHO, A.T., CARVALHO, D.A., VILELA, E.A., CURI, N. and FONTES, M.A.L., 2004. Diversity and structure of the tree community of a fragment of tropical secondary forest of the Brazilian Atlantic Forest domain 15 and 40 years after logging. Revista Brasileira de Botanica. Brazilian Journal of Botany, vol. 27, no. 4, pp. 685-701. http://dx.doi.org/10.1590/ S0100-84042004000400009.

ROSKOV, Y., ABUCAY, L., ORRELL, T., NICOLSON, D., KUNZE, T., CULHAM, A., BAILLY, N., KIRK, P., BOURGOIN, T., DEWALT, R.L., DECOCK, W. and DE WEVER, A., 2015 [viewed 18 May 2015]. Species 2000 \& ITIS Catalogue of Life, 18th May 2015. Netherlands: Naturalis, Leiden. Available from: www.catalogueoflife.org/col

SCHAEFER, C.W. and MITCHELL, P.L., 1983. Foods plants of the Coreiodea (Hemiptera: Heteroptera). Annals of the Entomological Society of America, vol. 76, no. 4, pp. 591-615. http://dx.doi. org/10.1093/aesa/76.4.591.

SCHAEFER, C.W., PACKAUSKAS, R. and BU, K., 2008. A new species of Leptoglossus (Hemiptera: Coreidae: Coreinae: Anisoscelini) from Brazil. Proceedings of the Entomological Society of Washington, vol. 110, no. 1, pp. 61-66. http://dx.doi. org/10.4289/0013-8797-110.1.61. 